\title{
Former Ottomans in the ranks: pro-Entente military recruitment among Syrians in the Americas, 1916-18*
}

\author{
Stacy D. Fahrenthold \\ Center for Middle Eastern Studies, University of California, Berkeley, California, USA \\ E-mail: fahrenthold.s@gmail.com
}

\begin{abstract}
For half a million 'Syrian' Ottoman subjects living outside the empire, the First World War initiated a massive political rift with Istanbul. Beginning in 1916. Syrian and Lebanese emigrants from both North and South America sought to enlist, recruit, and conscript immigrant men into the militaries of the Entente. Employing press items, correspondence, and memoirs written by émigré recruiters during the war, this article reconstructs the transnational networks that facilitated the voluntary enlistment of an estimated 10,000 Syrian emigrants into the armies of the Entente, particularly the United States Army after 1917. As Ottoman nationals, many Syrian recruits used this as a practical means of obtaining American citizenship and shedding their legal ties to Istanbul. Émigré recruiters folded their military service into broader goals for 'Syrian' and 'Lebanese' national liberation under the auspices of American political support.
\end{abstract}

Keywords First World War, Lebanon, mobilization, Syria, transnationalism

Is it often said that the First World War was a time of unprecedented military mobilization. Between 1914 and 1918, empires around the world imposed powers of conscription on their subjects while also placing new demands on civilian life to make provision for total war. In the Ottoman empire, these pressures produced some of the highest mortality rates seen beyond the battlefield: of the 2.8 million troops in the Ottoman army, an estimated 400,000 perished not in combat but because of insufficient provisioning and disease. ${ }^{1}$ Poor conditions and rumours

I would like to thank Devi Mays, Akram Khater, Beth Baron, Chris Rominger, and a supportive audience at North Carolina State University's Khayrallah Center for Lebanese Diaspora Studies for their critical insights made on early drafts of this work. My further gratitude goes to the editors at the Journal of Global History and two anonymous reviewers for their valuable commentary. The National Endowment for the Humanities 2014 Summer Seminar 'World War I in the Middle East' provided valuable research support.

1 Mehmet Beşikçi, The Ottoman mobilization of manpower in World War I: between volunteerism and resistance, Leiden: Brill, 2012, p. 261. 
of starving soldiers checked efforts by Ottoman Syria's governor-general, Cemal Pasha, to impose universal conscription on the Empire's Arab subjects (seferberlik), at the very moment when his government's dependence on the Arab home front reached its apogee. ${ }^{2}$ The empire faced what Mehmet Beşikçi calls the 'total war paradox': Istanbul's manpower needs depended on its ability to ensure civilian compliance, but its inability to secure adequate food, clothing, medicine, and munitions fed a growing manpower deficit, producing an army desertion rate that reached $17 \%$ by $1918 .^{3}$

In Ottoman Syria and Mount Lebanon, draft evasion was a common response to these pressures, but those who escaped fared no better than their conscripted countrymen. Ottoman requisitions of crops and supplies combined with a succession of poor harvests, locusts, and an Allied blockade to produce a devastating famine that killed $18 \%$ of western Syria's population by the war's end. ${ }^{4}$ Syrians with the means to do so fled abroad, joining emigrant communities where half a million Ottoman subjects (representing 20\% of the empire's Arab subjects) had lived since the turn of the century. ${ }^{5}$ By 1914, Syrian 'colonies' (jaliyyat) emerged in Egypt, West Africa, Europe, the Philippines, and Australia, but the diaspora's largest outposts were close to the coasts of the Atlantic in North and South America. ${ }^{6}$ Syrians living in São Paulo, Buenos Aires, and New York City may have been spared the war's harsher indignities but they were not entirely removed from its political pressures. The Ottoman government's inability to end the famine frustrated Syrians abroad, and Cemal Pasha's 1916 execution of Arabist dissenters compounded this anger, convincing activists that the homeland must be liberated from the 'Turkish yoke' (nir al-atrak) entirely. Ironically, those hanged in Syria in 1916 were not revolutionaries but advocates of imperial reform; news of their deaths prompted unprecedented efforts by Syrians abroad to demand independence for Syria and Mount Lebanon, and to promote revolt against Istanbul. ${ }^{7}$ The world war presented these activists with an opportunity for accomplishing national liberation.

In 1916, the Syrian diaspora transformed into a space for opposition against the Ottoman state, the circulation of revolutionary propaganda and for collaboration with the Entente powers. This article examines the diaspora's experience with military mobilization, documenting the recruitment of Syrian and Lebanese emigrants from the Americas into the

2 M. Talha Çiçek, War and state formation in Syria: Cemal Pasha's governorate during World War I, New York: Routledge, 2014.

3 Beşikçi, Ottoman mobilization, p. 7, 251.

4 Elizabeth Thompson, Colonial citizens: republican rights, paternal privilege, and gender in French Syria and Lebanon, New York: Columbia University Press, pp. 20-1; Melanie Schulze Tanielian, 'Feeding the city: the Beirut municipality and the politics of food during World War I', International Journal of Middle East Studies, 46, 4, 2014, pp. 737-58.

5 Charles Issawi, 'The historical background of Lebanese emigration, 1800-1914', in Albert Hourani and Nadim Shehadi, eds., Lebanese in the world: a century of emigration, London: I.B. Tauris and Centre for Lebanese Studies, 1992, p. 31; Kemal Karpat, 'The Ottoman emigration to America, 1860-1914', International Journal of Middle East Studies, 17, 2, 1985, pp. 175-209.

6 See Thomas Philipp, The Syrians in Egypt, 1725-1975, Stuttgart: Steiner, 1985; Andrew Arsan, Interlopers of empire: the Lebanese diaspora in colonial French West Africa, Oxford: Oxford University Press, 2014; William Gervase Clarence-Smith, 'Middle Eastern migrants in the Philippines: entrepreneurs and cultural brokers', Asian Journal of Social Science, 32, 3, 2004, 425-57; Anne Monsour, Not quite white: Lebanese and the white Australia policy, Brisbane: Post Pressed, 2010; John Tofik Karam, Another arabesque: SyrianLebanese ethnicity in neoliberal Brazil, Philadelphia, PA: Temple University Press, 2007; Akram Khater, Inventing home: emigration, gender, and the middle class in Lebanon, 1870-1920, Berkeley, CA: University of California Press, 2001.

7 Çiçek, War and state formation, pp. 39-76; Hasan Kayal, Arabs and Young Turks: Ottomanism, Arabism, and Islamism in the Ottoman empire, 1908-1918, Berkeley, CA: University of California Press, 1997, pp. 193-6. 
French, Canadian, and American armies. Émigré activists promoted enlistment with the Entente as a means of accomplishing Syria's independence from the Ottomans. And enlist they did: an estimated 10,000 ethnic Syrians had joined the United States army by 1918, many of them former Ottoman nationals. ${ }^{8}$ Smaller numbers of Syrians also volunteered for the Frenchled Légion d'Orient and the Canadian Expeditionary Forces. ${ }^{9}$

Syrian émigré recruiters presided over a transnational, largely clandestine mobilization project that produced a lateral traffic in volunteers between immigrant communities in the United States, Brazil, Argentina, and elsewhere in the Americas. The soldiers whom they raised navigated a complicated legal terrain between the Ottomans and the Entente, and they depended on a sophisticated network of recruiters to help them acquire the new passports, visas, and naturalization documents they needed to enlist. Recruiters mediated between foreign governments and a growing pool of Syrian migrants to exact favourable terms for their men. Syrians living in the diaspora widely saw military service as a practical means of achieving a post-Ottoman nationality status, particularly after the United States entered the war on 6 April 1917 and extended citizenship rights to foreign-born volunteers the following year. Syrian men who deployed (almost always to European, not Ottoman, fronts) described their status as a partnership with America fighting for Syrian liberation. Theirs was a multi-layered and flexible patriotism that allowed soldiers to become 'Syrian' and 'American' simultaneously through service and action. ${ }^{10}$

The enlistment of Syrian migrants required a significant amount of work: medical testing, the provision of new travel documentation, and often changes in nationality to ensure the process's legality. Each facet brought recruiters into close relationships with foreign government officials, most notably the French Foreign Ministry and (in 1917) the US Department of State. At the same time, the Syrian agents who managed the process of recruiting, screening, and transporting new volunteers to enlistment sites worked clandestinely, in liminal legal spaces that the Entente powers informally sanctioned but did not oversee. Consequently, examining Syrian enlistment practices requires investigating the correspondence, press clippings, and memoirs of individual recruiters, soldiers, and their agents, most of whom worked beyond the archival confines of the state. Employing these materials, this article tracks the movement of Arabophone Ottoman emigrants from Greater Syria (including Mount Lebanon and Palestine) into military collaboration with the Entente. The recruiters and soldiers discussed here belonged to one of four groups: Ottoman nationals in diaspora, 'Syrian'

8 Precise Syrian numbers are difficult to come by. Contemporary sources report that 12,000 to 15,000 Syrians served in the US army, a figure that is almost certainly too high. See John Moroso, 'Fall of Damascus thrills our Syrians', New York Times, 6 October 1918, p. 48; US National Archives and Records Administration, Record Group 59, Records of the State Department relating to World War I and its termination (henceforth NARA, RG 59), M367, roll 392, 763.72119/3456, George Khairallah to Frank Polk, State Department, 15 January 1919 , p. 2. See also NARA, RG 59, M367, roll 392, 763.72119/4555, Hampson Gary to Robert Lansing, 'Transmitting a memorandum called "America and Syria"', 27 February 1919, pp. 5-6. In 1924, Philip Hitti enumerated 13,965 enlistments in his study, The Syrians in America, New York: G.H. Doran, 1924, p. 102. Sarah Gualtieri points out differences between Hitti's figure and rates as high as 15,000 described by the Syrian American Club (in writings by one of its members, George Khairallah). Comparisons with Selective Service records, the Naturalization Index, and Army cards suggest that closer to 10,000 Syrian immigrants served at least one enlistment term. Sarah Gualtieri, Between Arab and white: race and ethnicity in the early Syrian American diaspora, Berkeley, CA: University of California Press, 2009, p. 210, n.18.

9 Gabriel Ilyas Ward, Kitab al-Jundi al-Suri fi-Thalatha Hurub (The Syrian soldier in three wars), New York: al-Matba'a al-Tijariyya al-Suriyya al-Amrikiyya, 1919, p. 72.

10 Akram Fouad Khater, 'Becoming “Syrian” in America: a global geography of ethnicity and nation', Diaspora: Journal of Transnational Studies, 14, 2/3, 2005, pp. 299-300. 
foreign residents in the Americas with incomplete naturalization status, naturalized Syrian Americans, and second-generation Syrian Americans born abroad. Where Syrian volunteers fell on this scale bore consequences for their ability to enlist, creating obstacles that recruiters confronted on a case-by-case basis.

These recruiters promoted Syrian participation in Allied efforts in the belief that the war would liberate their Middle Eastern homeland from Ottoman rule, an idea deployed similarly by British, French, and American policymakers. ${ }^{11}$ Although such sentiments would later be touted as evidence of an authentic nationalist spirit in the diaspora, the reality was that this wartime activism was neither purely sentimental nor entirely nationalist in content. Military mobilization was a political act that recruiters linked closely with ideas about Syria's liberation from the Ottoman government. It was not just about patriotic sentiment, longing, or an emotional connection to the homeland, however, but about the definitive action they inspired. ${ }^{12}$ This distinction is important because, by casting new patriotic responsibilities upon emigrant men on behalf of 'martyred Syria', recruiters did not merely 'imagine' the existence of a Syrian (as opposed to an Ottoman) national community. ${ }^{13}$ Rather, they worked towards Syria's armed reclamation from Istanbul and used the enlistment campaign to build partnerships with foreign governments to enforce it. These were not Syrian exiles engaged in collective nostalgia; they were Syrians abroad, dynamic participants in a transnational politics that joined Syria to its diaspora, the Mashriq to the mahjar, and which outlived the 1918 armistice.

Working with the Entente placed Syrian recruiters and soldiers alike into a difficult, unsettled legal space between the Ottoman empire and its enemies. Whether these men would be remembered as patriots or traitors depended largely on the war's outcome, and Ottoman nationals fighting for the Allies risked the possibility of statelessness as thanks for their efforts. The French, Canadian, and American governments all readily offered travel documents to their foreign volunteers, but concerns about fighters' nationality status lingered until the United States offered them unfettered access to US citizenship in 1918. As shall be seen, a documentary hierarchy emerged among recruiters as they promoted service with America as a means of shedding one's Ottoman nationality. ${ }^{14}$

Recruiters helped enlistees obtain passports and documentation to distance themselves from the Ottoman empire, which formally claimed them as subjects, but Syrian emigrants also expressed fears that joining the military would open them up to prosecution by Turkish authorities. On the one hand lay charges of treachery; on the other, American nativist accusations of immigrant cowardice, 'slackerism', or disloyalty. Syrian enlistees faced a

11 James Renton, 'Changing languages of empire and the Orient: Britain and the invention of the Middle East, 1917-18', Historical Journal, 50, 3, 2007, pp. 645-70.

12 Nina Glick Schiller and Georges Fouron, Georges woke up laughing: long-distance nationalism and the search for home, Durham, NC: Duke University Press, 2001, p. 20; Manu Goswami, 'Rethinking the modular nation form: toward a sociohistorical conception of nationalism', Comparative Studies in Society and History, 44, 4, 2002, pp. 77-9; Isa Blumi, Ottoman refugees 1878-1939: migration in a post-imperial world, London: Bloomsbury, 2013, pp. 79-82.

13 NARA, RG 59, M367, roll 394, 763.72119/3841, New Syrian National League/Syrian American Club joint telegram to Robert Lansing, Secretary of State, 23 February 1919; Benedict Anderson, Imagined communities: reflections on the origins and spread of nationalism, London: Verso, 1992.

14 Will Hanley, 'Papers for going, papers for staying: identification and subject formation in the eastern Mediterranean', in Liat Kozma, Cyrus Schayegh, and Avner Wishnitzer, eds., A global Middle East: mobility, materiality, and culture in the modern age, London: I.B. Tauris, 2014, pp. 190-2; John C. Torpey, The invention of the passport: surveillance, citizenship, and the state, Cambridge: Cambridge University Press, 2000. 
difficult legal quandary, which one prominent recruiter described as being caught 'between treason and cowardice' (bayna al-khiyana wa-l-jabana): simultaneously compelled and forbidden to join the fight, many remained in a liminal station between Ottoman and American citizenships, fuelling wider conversations about political belonging in the diaspora. ${ }^{15}$ As Syrian American troops were shipped abroad in 1918, the Syrian press published soldiers' images, biographies, and letters home, using them as material evidence of their patriotism and of the diaspora's political contract with the Entente. Nationalist political parties used the soldiers as symbols, folding them into Wilsonian narratives about self-determination through service and action. The connection between soldiering and nationalism persisted through to the 1918 armistice, but Syrian American troops also objected to political uses of their personal legacy.

\section{'Saving the East from the claws of barbarism:' the French Légion d'Orient as precursor ${ }^{16}$}

The Syrian diaspora's experience with pro-Entente mobilization began in 1916, with the formation of a French irregular corps called the Légion d'Orient. A mixed infantry regiment comprised largely of Armenians (who numbered around 4,000) under French officers, the Légion d'Orient employed 550 Syrian and Lebanese emigrants recruited from Egypt, Europe, and the Americas. ${ }^{17}$ In the Americas, ethnic fraternal societies promoted French war aims, identified new recruits, and sponsored their passage to France's enlistment sites in Bordeaux, Marseille, and Le Havre. ${ }^{18}$ The employment of Syrian irregulars dovetailed with a much larger French usage of colonial troops in combat, but the Légion d'Orient was not a unilaterally French project. ${ }^{19}$ Simon Jackson argues that, for Syrian leaders in France and the Americas, 'the war presented an opportunity to advance a variety of simmering plans for the geopolitical future of the post-Ottoman Middle East' and they aggressively lobbied the corps. ${ }^{20}$ Though nominal in size, its value was touted by the French Foreign Minister, Georges-Picot, as a symbolic manifestation of Syrian collaboration and support for France's Levantine ambitions. ${ }^{21}$ The Légion d'Orient was deployed to Palestine in 1917, where it helped British forces under Edmund Allenby to secure Nablus for the allies. ${ }^{22}$

Syrian recruiters in São Paulo, Rio de Janeiro, Buenos Aires, Havana, and New York City levied emigrant men for the Légion d'Orient between late 1916 and 1917. The Paris-based Comité Central Syrien (CCS) under Shukri Ghanim and Georges Samné led the effort, and, as a result, historians have understood the project as an extension of the CCS's pan-Syrian

15 Na um Mukarzil, 'Fi kull yawm khitab (Every day, a speech)', al-Huda, 7 June 1917, p. 2.

16 Shukri Bakhash, 'Bayna al-Midhwad wa-l-Khandaq (Among troughs and trenches)', al-Fatat, 22 December 1917 , p. 1.

17 Eliezer Tauber, 'La Légion d'Orient et la Légion arabe', Revue française d'histoire d'outre-mer, 81, 303, 1994, p. 172.

18 Ibid., pp. $172-4$

19 Richard S. Fogarty, Race and war in France: colonial subjects in the French army, 1914-1918, Baltimore, MD: Johns Hopkins University Press, 2008; Gregory Mann, Native sons: West African veterans and France in the twentieth century, Durham, NC: Duke University Press, 2006.

20 Simon Jackson, 'Global recruitment: the wartime origins of French Mandate Syria', in Alison Carrol and Ludivine Brock, eds., France in the era of global war, 1914-1945: occupation, politics, empire, Basingstoke: Palgrave MacMillan, 2014, p. 137; N. E. Bou-Nacklie, 'Les Troupes Spéciales: religious and ethnic recruitment, 1916-46', International Journal of Middle East Studies, 25, 4, 1993, pp. 647-8.

21 Jackson, 'Global recruitment', p. 138. Tauber, 'Légion d'Orient', p. 174; Bou Nackhlie, 'Troupes Spéciales', pp. 648-9.

22 Shukri Bakhash, 'Nahu Suriya (About Syria)', al-Fatat, 19 December 1917, p. 1. 
nationalist politics. Ghanim promoted Greater Syria's separation from the Ottoman empire and its placement under direct French tutelage in the name of national development. ${ }^{23}$ Although the CCS was perhaps the diaspora's most popular nationalist movement during the war, Ghanim's influence waned swiftly in 1919 as France endorsed the creation of a Lebanese state (the Grand Liban) at the expense of CCS demands for territorial unity.

Although the Légion d'Orient had been Ghanim's idea, both 'Syrianists' and 'Lebanists' recruited for the corps and claimed the legionaries as symbols of their alliance with France. ${ }^{24}$ Indeed, the diaspora's most successful recruiters did not share Ghanim's politics: in New York City, São Paulo, and Rio de Janeiro, a political party called the Jam iyyat al-Nahda al-Lubnaniyya (the Lebanon League of Progress) provided most of the Légion d'Orient's recruitment services (see Figure 1). ${ }^{25}$ Like the CCS, the Lebanon League endorsed French tutelage, but they also lobbied for the creation of a Lebanese state distinct from Syria. The party's leaders, the prominent Lebanists Nacum Mukarzil in New York City and Shukri al-Khuri in São Paulo, worked with the CCS but otherwise described Ghanim as a political rival. Although trenchant and intensifying ideological divisions between Syrianist and Lebanist leaders later boiled over in 1918, the difficult work of diasporic recruitment demanded that they collaborate, and they did so on the shared, practical belief that 'France will liberate [our] country and break the heavy Turkish yoke that has treated us so severely, subjecting us to famine and starvation'. ${ }^{26}$ Mukarzil described mobilization as one half of a political contract he would later bring to the Americans: manpower in return for partnership in homeland liberation. But, like the boundaries of the homeland itself, the ideological content of Syrian and Lebanese patriotism remained less immediately relevant than the drive to build functional political alliances.

In the United States, Mukarzil's Lebanon League of Progress raised US\$100,000 to assist emigrants in joining the Légion d'Orient in 1917; a large portion of this sum came from the French government, according to Mukarzil (although he never disclosed how much). ${ }^{27}$ With this funding, he presided over a new migration network linking his office in Brooklyn to recruiters working in São Paulo, Buenos Aires, Havana, and Mérida, Mexico. Each city hosted satellite chapters of the Lebanon League, which furnished recruits with French passports and passage to New York City. After medical testing and vetting by Mukarzil, the men were given steamship tickets to Bordeaux, where they formally enlisted in the French infantry. ${ }^{28}$ Syrian volunteers from South America, the United States, and Canada made the lateral migration to New York to participate in Mukarzil's campaign, facilitated in part by shipping lines managed by Lebanon League partisans and Mukarzil's relatives in South America. ${ }^{29}$

All of the work of vetting new soldiers was done in New York, save for the act of enlisting itself, which happened upon arrival in France. Citing its own neutrality in the war, the

23 Andrew Arsan, " "This age is the age of associations": committees, petitions, and the roots of interwar Middle Eastern internationalism', Journal of Global History, 7, 2, 2011, pp. 186-7; Simon Jackson, 'Diaspora politics and developmental empire: the Syro-Lebanese at the League of Nations', Arab Studies Journal, 21, 1, 2013, pp. 169-71.

24 This terminology is borrowed from Carol Hakim, The origins of the Lebanese national idea, 1840-1920, Berkeley, CA: University of California Press, 2013, pp. 217-20.

25 Eliezer Tauber, The Arab movements in World War I, London: Frank Cass, 1993, pp. 197-9.

26 Recruitment announcement, Jam'iyyat al-Nahda al-Lubnaniyya (Lebanon League of Progress), 'Ila al-Watan Yahama al-Watan (To the nation, to protect the nation)', al-Huda, 1 May 1917, p. 4.

27 The French funded the CCS in Paris at similar levels: see Tauber, Arab movements, p. 209.

28 al-Nahda, 'Ila al-Watan', p. 4. The Lebanon League kept two doctors on retainer: Rashid Baddur and Najib Barbur in New York. 


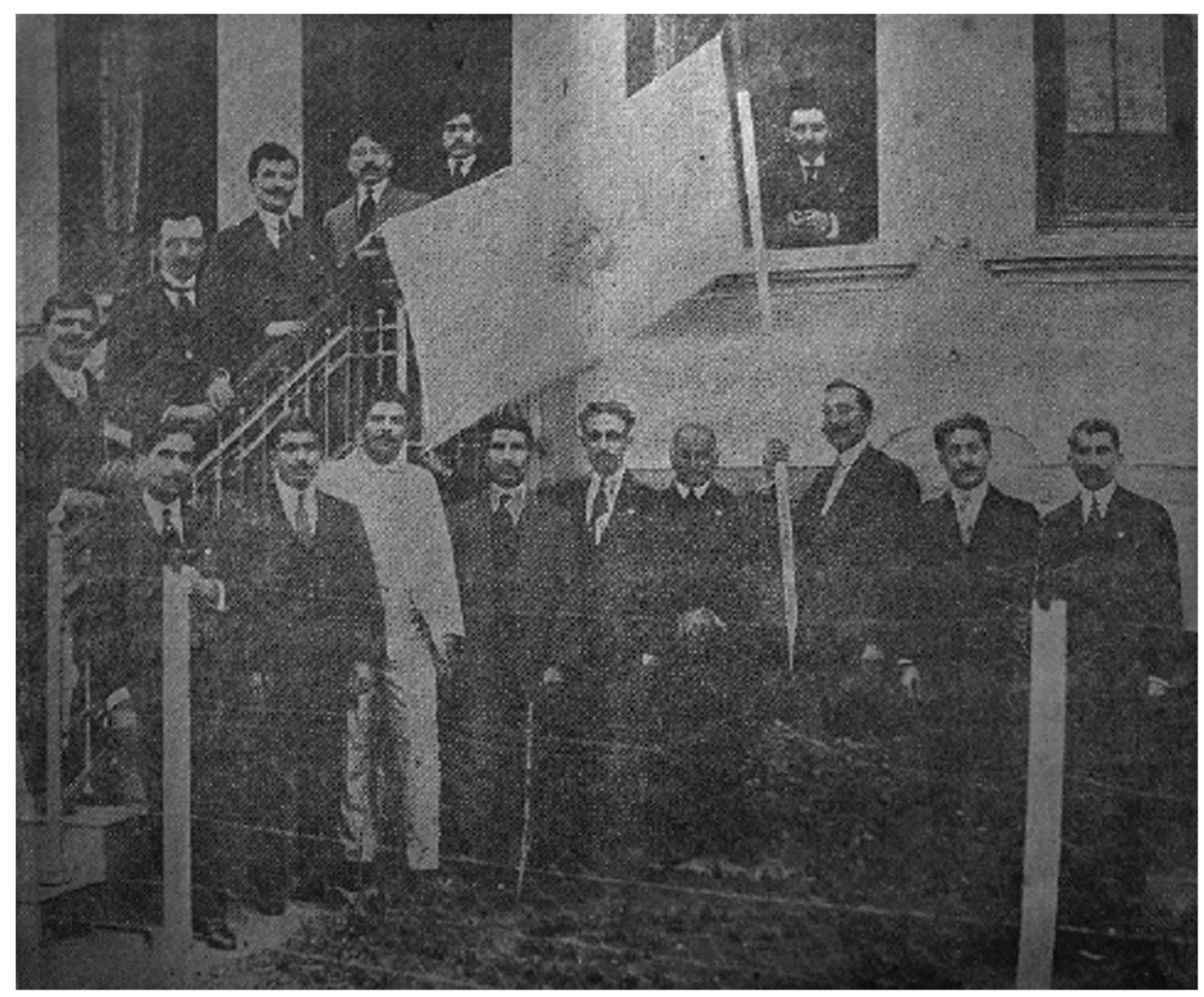

Figure 1. Lebanon League of Progress Executive Committee in São Paulo, 1914. President Shukri al-Khuri appears in the window; Shukri Bakhash (who later became a rival recruiter in New York) is in the front row, second from right. Source: Jamiyyat al-Nahda al-Lubnaniyya pamphlet, 29 September 1914, p. 3.

US Department of State allowed the recruitment (but not the enlistment) of foreign troops on its soil. ${ }^{30}$ The process's piecemeal nature and its management by private émigré recruiters made New York City a locus for the diaspora's mobilization, but it also created opportunities for enterprising migrants seeking free passage across the Americas or to Europe. ${ }^{31}$ Simon Jackson points out that the Légion d'Orient suffered attrition as recruits occasionally deserted upon arrival in France. ${ }^{32}$

The Lebanon League of Progress printed daily calls for recruits in Mukarzil's newspaper in New York City, al-Huda (Guidance); similar announcements appeared in Abu al-Hawl (The Sphinx), the party's São Paulo organ. The call to arms placed emigrant soldiers within a very specific political project:

For recruitment and jihad in the name of humanity. Pay heed, oh sons of Lebanon! The Turks are dividing your land ... it is our goal to expel the Turks from Syria, to cut

30 NARA, RG 59, M367, roll 475, 763.72119/9557, Hugh Cleveland to Bainbridge Colby, Secretary of State, 'Reason for creation of Eastern Legion', 10 March 1920, pp. 4-5.

31 Shukri Bakhash, 'al-Wizarat al-Harbiyya al-Fransawiyya wa-l-Firq al-Sharqiyya (The French War Ministry and the Légion d'Orient)', al-Fatat 19 December 1917, p. 2.

32 Jackson, 'Global recruitment', p. 143. 
the cords from those gallows once looped over the heads of [Lebanon's] men who dared talk about independence, the honourable, intelligent effendis of the nation. Oh sons of the nation, [we] advise you move to the places French soldiers are. The Lebanon League of Progress is ready and prepared to help volunteers enlist, and to dispatch them under the protections and liberties afforded to them by the government of France. ${ }^{33}$

The Lebanon League managed a lateral traffic in recruits moving across the Americas for mobilization purposes. Even with the provision of passports, transatlantic passage, and guaranteed diplomatic protections, the League's return on recruitment was more trickle than torrent. The Syrian legionaries never amounted to more than 550 in a predominantly Armenian force. ${ }^{34}$

Several factors mitigated the campaign's success. Critics pointed out that, although France supplied foreign soldiers with passports, it did not offer them French citizenship or even permanent residency rights. Syrian troops were in a complicated legal position and those with Ottoman nationality opened themselves up to possible treason charges. Deployed soldiers wrote to al-Huda and tried to 'address the concerns of Syrians who fear their legal attachments to the Turks [and] of being potentially disgraced as traitors' by arguing that holding French passports would protect them from prosecution. ${ }^{35}$ At the same time, others feared (correctly) that the Légion d'Orient would become a tool of French colonial policy aimed at exacerbating new and painful divisions between Syrian Christians and Muslims. ${ }^{36}$

The perception that the Légion d'Orient served French colonial interests prompted some Syrians to seek other means of enlistment. In New York City, a smaller stream of naturalized Syrian Americans migrated further north to enlist with the Canadian Expeditionary Forces. Canada prohibited Ottoman nationals from serving in its military but encouraged its own Syrian immigrants to naturalize as Canadian citizens and join up. The Canadian Expeditionary Forces also welcomed Syrian Americans into its ranks, encouraging those who had achieved US citizenship or declared their intent to naturalize to enlist. ${ }^{37}$ In his memoirs published in 1919, an intelligence officer named Gabriel Ilyas Ward (see Figure 2) recounted his own enlistment experience. Originally from Tripoli, Ward moved to New York in the 1890s, became a US citizen, and twice served in the US army, in the Philippines (1898) and in Mexico (1912). ${ }^{38}$ He was working as a dry goods wholesaler between New York City and Nova Scotia when the war broke out in 1914. Frustrated by American neutrality, Ward and several of his business partners left the United States, enlisted in Montreal, and arrived at the French trenches by early 1916 .

Ward's enlistment appears to have been the result of his spontaneous decision, but Canada also hosted active recruitment centres managed by Syrian immigrants. From Montreal, the recruiters Ilyas Yusuf and Shakir Karam advertised widely for new volunteers, targeting the Arabic newspapers in New York City, where they competed with Mukarzil's Francophile

33 al-Nahda, 'Ila al-Watan', p. 4.

34 Tauber, Arab movements, pp. 200-1.

35 Gabriel Ilyas Ward, "ar an la-Tasil dama'una illa 'ala khanja al-saffah ('Shame that our blood does not flow, except from the Butcher's [Cemal Pasha's] dagger)', al-Huda, 2 June 1917, p. 3.

36 Tauber, Arab movements, p. 211.

37 Ilyas Yusuf and Shakir Karam, 'al-Suriyyun wa-l-khidma al-'askariyya fi-Kanada (The Syrians and Canadian military service)', al-Nasr, 18 January 1918, p. 3, translation of public address given on 3 November 1917.

Ward, Kitab al-jundi al-Suri, pp. 61-4. 


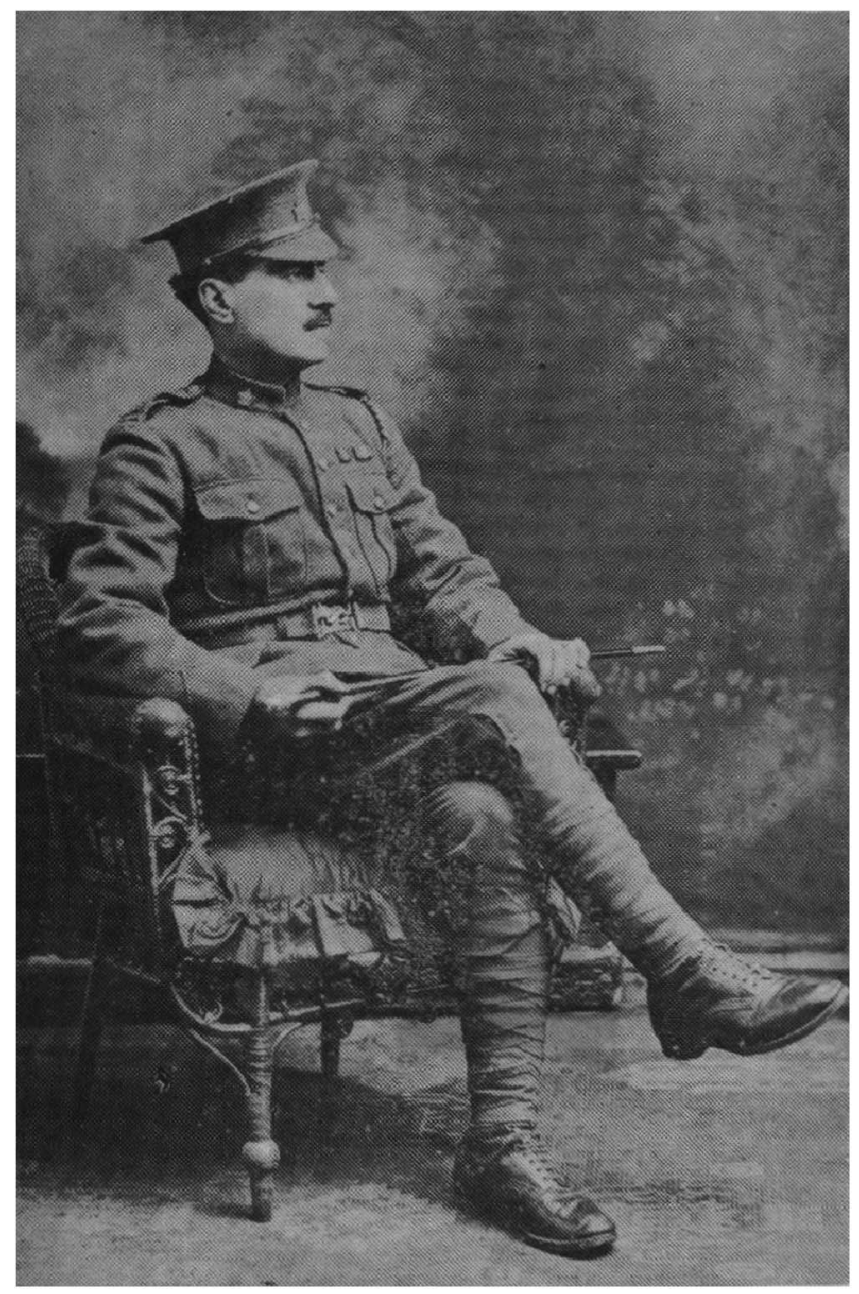

Figure 2. Gabriel Ilyas Ward, 1919. Military intelligence officer and recruiter, seated in profile to obscure his injuries. Source: AANM, ES, Syrian American Club of Boston Records, 1, 5.

Lebanon League of Progress. ${ }^{39}$ In a 1917 letter in al-Bayan (The Declaration) addressed to the Syrians of New York, Karam announced his partnership with British officials to levy Syrian volunteers on behalf of the Canadian Expeditionary Forces. ${ }^{40}$ The campaign particularly encouraged Muslim volunteers. Though the recruitment of Syrians in the French and US militaries was almost entirely limited to Christians, Karam passed along assurances from the Canadian Minister of Justice, A. L. Newcombe, that his country 'draws no legal distinction between Christians and Muslims' in matters of eligibility. ${ }^{41}$ Syrian volunteers made strategic decisions when opting for military service within French or Canadian units, depending on an

39 Yusuf and Karam, 'al-Suriyyun wa-l-khidma al-'askariyya', p. 3.

40 'al-Tajnid al-Inklizi huna (The British recruitment here)', al-Bayan, 2 June 1917, p. 1.

41 Yusuf and Karam, 'al-Suriyyun wa-l-khidma al-'askariyya', p. 3. 
amalgam of desires to work in service to French or British interests and more practical issues such as the terms of service, quality of provisions, or pay. America's entry into the war in 1917 largely frustrated both recruitment flows in favour of entry into the US army, but small numbers of Syrians continued to enlist with either French or Canadian units until 1918. Choice of destination also influenced enlistees' decisions: Syrians Americans fighting for France could opt for a front against the Ottomans, but those in American or Canadian units were limited to the European theatre.

Although most of the Syrian diaspora's recruiters stated their preference that Syrians fight against the Ottomans, the American option was particularly attractive to recruiters of Lebanese and Arab nationalist persuasions alike. Mukarzil, for instance, recommended the US army and the Légion d'Orient simultaneously until June 1917, but he became particularly suspicious of the French legionaries after the CCS sent its own delegation to South America. Dr Qaysar Lakah and Jamil Mardam Bey toured Brazil looking for new recruits, but Mukarzil suspected that the tour was designed to undercut his own recruitment work and to solidify the Légion d'Orient as a Syrianist project. In al-Huda, Mukarzil hastened to support Syrian enlistment in the US army instead and even deployment to alternative battlefields:

This publication looks favourably on Syrian and Lebanese volunteerism for the homeland's recovery ... but it also supports Syrian and Lebanese volunteers being deployed to alternative fronts and battlefields. If compelled to duty, we will report to the African Sahara, the European trenches, or anywhere else, for we have one single purpose, and that is to fight until freedom (burriyya) is victorious. ${ }^{42}$

al-Huda was not the only diasporic paper to endorse enlistment in the US military as an alternative to the Légion d'Orient; New York's growing community of Syrian and Arab nationalists also did so, in a bid to build a partnership with Wilson's America for their respective movements. The most notable such group was the Syria-Mount Lebanon League of Liberation (Lajna Tahrir Suriya wa-Lubnan) under Ayyub Tabet, Amin Rihani, and N. T. Tadross. Shukri Bakhash (see Figure 3), the editor of al-Fatat newspaper, was the League of Liberation's primary recruiter. ${ }^{43}$

\section{America's Selective Service draft and legal ambiguities surrounding Syrian immigrants}

In April 1917, President Woodrow Wilson committed his country to war and announced that the United States would raise 4 million soldiers to join Allied troops on the Western Front. Most of these troops were levied in the largest compulsory draft in American history: the Selective Service draft of 1917. President Wilson's commitment to fighting 'for the liberation of nations and oppressed peoples around the world' against 'the spirit of autocracy that has shattered the weak peoples under its yoke' prompted Syrian immigrants to support the call to arms and, over the course of the war, the president would become one of the most revered

42 'al-Khawatir: bayna al-harb wa-l-tard wa-l-sajn (Reflections: between war, expulsion, and imprisonment)', al-Huda, 3 May 1917, p. 5.

43 NARA, RG 59, M367, roll 381, 763.72119/1686, E. Tabet and Mikhail Naimy to President Wilson, 10 May 1918, pp. 1-2. 


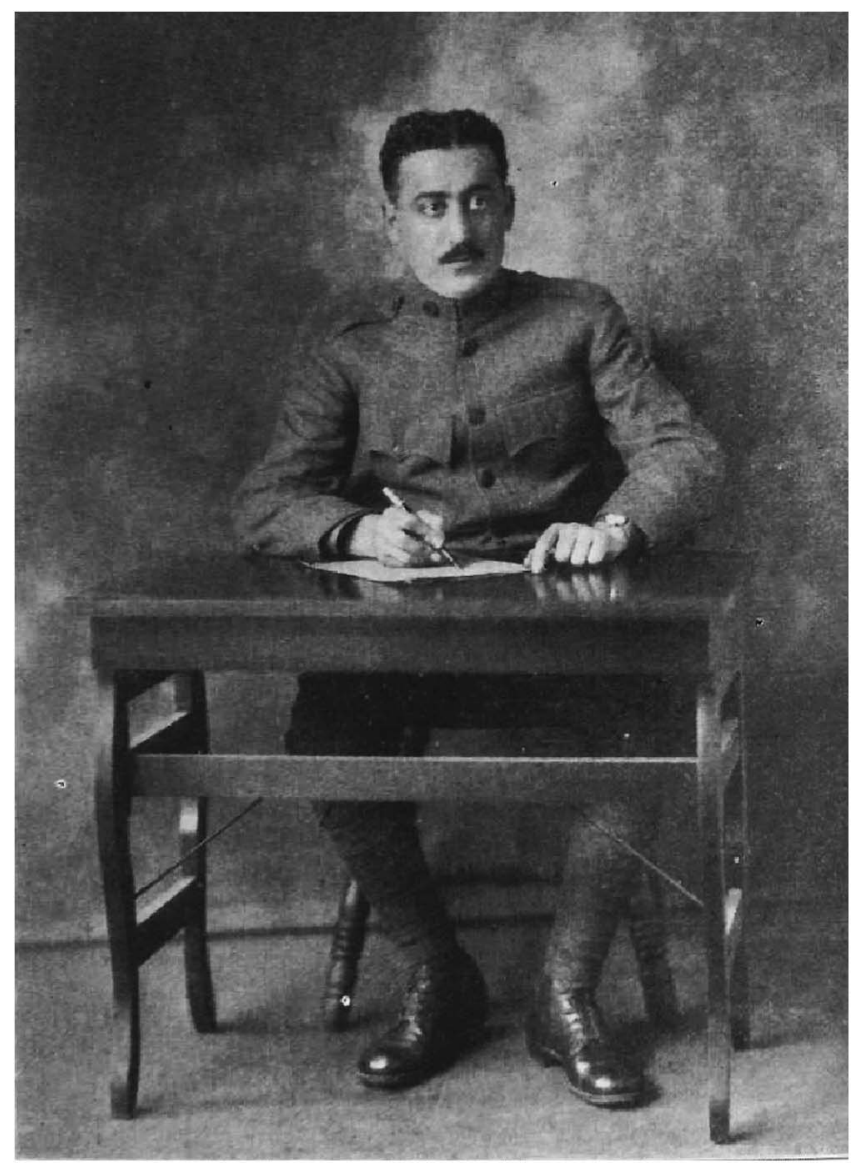

Figure 3. Shukri Bakhash, editor of al-Fatat, 1917. A recruiter for the US army and a War Department propagandist, Bakhash called his efforts a 'literary jihad' against the Ottoman government. Source: Ward, Kitab al-jundi al-Suri, p. 115.

personalities for Syrian, Lebanese, and Arab nationalists alike. ${ }^{44}$ In the United States, the same newspaper editors who endorsed America's war effort also led the first campaigns to enlist Syrians in the army: Na um Mukarzil (al-Huda), Shukri Bakhash (al-Fatat (Youth)), Ibrahim al-Khuri and Wadi Shakir (Fatat Boston, al-Fatat's sister publication), among others. Of course, the draft's implementation immediately raised questions about Syrian eligibility for military service. While recruiters saw Syrian enlistment in the US army as a natural extension to work already being done with America's allies, the US Provost Marshal, Enoch Crowder, was reticent about including Ottoman nationals in the army's ranks. Could Syrian immigrants be compelled to serve? What about those who retained their Ottoman nationality and were thus neutral allies of America's German enemy?

Like native-born American citizens, all foreign-born immigrants and foreign nationals were required to register with the Selective Service boards, which then chose eligible men

44 Ward, Kitab al-jundi al-Suri, p. 73; Erez Manela, The Wilsonian moment: self-determination and the origins of anticolonial nationalism, Oxford: Oxford University Press, 2007, pp. 23-55. 
for compulsory military service. Unnaturalized foreign-born registrants were classified in one of three categories: declarant (having submitted a Declaration of Intent, the first papers required of immigrants seeking to naturalize), non-declarant (retaining a foreign nationality), or enemy alien. Enemy aliens were, by virtue of international law, ineligible for the draft: these men 'would not be compelled to serve ... since they would be in a position of fighting their own countrymen'. ${ }^{45}$ But the legal standing of Ottoman nationals remained particularly murky, especially for Ottoman non-declarants. Because the United States never declared war on the Ottoman empire, Ottoman subjects living in the country became 'neutral allies of the enemy'. Like enemy aliens, 'neutral allies of the enemy' could not be compelled to serve, but they could volunteer or otherwise opt into service if mistakenly drafted. On the face of it, this granted Ottoman immigrants a legal status distinct from that of German, Austrian, or Czech immigrants. ${ }^{46}$ In practice, however, Syrian non-declarants were routinely dismissed from the army, misclassified in draft documents as 'alien enemies' alongside other groups of ineligible foreigners. This practice was so common that some Syrian draftees successfully evaded the draft (or received early discharge from service) by invoking 'alien enemy' status. ${ }^{47}$ Such ambiguities surrounding the military eligibility of Ottoman immigrants worried Syrian recruiters as they sought to widen (not contract) the pool of available troops. ${ }^{48}$

Not to be outdone by the draft's classification scheme, recruiters found room to navigate the process and place men in the US army. A common strategy involved starting the naturalization process just prior to enlistment. In al-Huda newspaper, Mukarzil reported that, although all Syrian men between the ages of twenty-one and thirty-one must register with the Selective Service Board, only those bearing their 'first papers' (that is, a Declaration of Intent) would be eligible for voluntary induction. A recent court case, Dow vs. United States (1915), had assured Syrian immigrants access to US citizenship. Mukarzil argued that, by submitting their first papers before registering with the Selective Service Board, Syrian men would bolster their citizenship petitions by serving America as declarant immigrants as opposed to 'neutral allies of the enemy'. Citing new legislation which distinguished between 'Lebanonites or Syrians claimed by Turkey as a subject' and ethnic Turks, he pointed out that military service was the first step towards US citizenship. 'The war has prompted the American government to distinguish the Syrians and Lebanese from those who are clearly Turks', he admonished his readers. ${ }^{49}$ For Mukarzil, this was evidence that Americans saw Syrian and Lebanese aspirations for independence as legitimate and would support them.

Mukarzil did not mention the religious connotations behind these labels in his editorial, but it is worth noting that, in American legal parlance, the conflation of 'Turk' with Muslim and 'Syrian' with Christian was never far from the surface. Another outcome of Dow v. United States was the creation of a 'Syrian' ethnicity that was racially white, Christian, and eligible for

45 Second Report of the Provost Marshal General to the Secretary of War on the operations of the Selective Service system to December 20, 1918, Washington, DC: Government Printing Office, 1919, pp. 86-8.

46 Nancy Gentile Ford, Americans all! Foreign-born soldiers in World War I, College Station, TX: Texas A\&M University Press, 2001, pp. 60-1.

47 See, for instance, New York State Archives, Adjutant General's office, Abstracts of World War I military service, 1917-1919, series B0808-85, draft cards for Alex Assa, service number 1929681, 25 September 1917, and for Taufik Hazaz, service number 3194840, 28 May 1918.

48 Na'um Mukarzil, 'al-Lubnaniyyun wa-l-Suriyyun tujaha al-khidma al-'askariyya (The Lebanese and Syrians facing military service)', al-Huda, 1 June 1917 , p. 3.

Ibid., p. 3. 
American citizenship on those bases. ${ }^{50}$ The wartime distinction between 'Syrians' and 'Turks' presented an extension of this logic, and it opened military service up to Arab Christian immigrants while offering them a means of establishing a post-Ottoman nationality status and some recognition as simultaneously American and 'Syrian' (or 'Lebanese', as Mukarzil insisted).

One significant obstacle persisted: US immigration law required that all new declarants reside in-country for five continuous years before applying for their 'second papers', the petition for naturalization. Critically, Syrians who entered this waiting period formally remained subjects of the Ottoman empire. In cases where Syrian declarants fought for the American military, they risked statelessness or prosecution by the Ottoman government. Concerned about the quandary, Mukarzil wrote to Crowder to inquire whether Syrian volunteers could be excused from the five-year residency requirement; a system of sponsorship could replace the waiting period, and naturalized Syrians could vouch for their compatriot soldiers. ${ }^{51}$ Such a change, he argued, would transform Syrian soldiers into American citizens overnight, mitigating legal problems arising from their option to serve.

The idea to offer citizenship to Syrian volunteers fell on deaf ears in 1917, and Provost Marshall Crowder remained wary of the diplomatic issues that instant naturalization could raise. In May 1918, the army would revise its enlistment policies in just this way, but until that time the majority of Syrian volunteers levied were either second-generation Syrian Americans (American citizens by virtue of birth) or long-time declarants who took the final step to naturalize as they joined the army. Recruiters for the Légion d'Orient and the US army competed for immigrant attentions throughout 1917, and Mukarzil, Bakhash, and their partisans filtered manpower through US, French, and Canadian channels on the basis of citizenship status and soldiers' preferences about destination.

\section{‘Every day, a speech:' campaigns for emigrant recruitment, 1917-18}

After President Wilson declared war, the Syrian diaspora hosted several mass recruitment fairs, complete with public square meetings and bathed in a multivalent discourse about patriotism with the feel of a carnival. In the United States, al-Huda, al-Fatat, and Fatat Boston newspapers celebrated deployed soldiers, and fraternal organizations hosted festivals open to the community at large. At these meetings, token Syrian soldiers appeared in uniform and shared their experiences with the crowd; the emigrant community's rich supply of poets, playwrights, and journalists followed up with speeches. The Lebanon League of Progress sponsored one such rally in Boston in May 1917. Some 2,000 Syrian and Lebanese immigrants attended, among them the rector of Brooklyn's Our Lady of the Cedars Maronite Church, Joseph Yazbek, the Syrian American Club (al-Muntada al-Suri al-Amriki) recruiter and Fatat Boston editor, Wadic Shakir, and the French consul, Joseph Flamand. The mass meeting featured speeches about Syrians' patriotic obligation 'to enlist under the Stars and Stripes, and to fight for the greatest

50 Gualtieri, Between Arab and white, pp. 58-61, 84.

51 Mukarzil, 'al-Lubnaniyyun wa-l-Suriyyun', p. 3.

52 Na'um Mukarzil, 'Fi kull yawm khitab'. 
democracy in the world'. ${ }^{53}$ One of the community's enlisted men, Elias F. Shannon, appeared in uniform and addressed other second-generation Syrians. ${ }^{54}$

The immigrant press cast Syrian recruitment in the language of patriotic duty, and other forms of immigrant patriotism - reprinting of propaganda from the Committee for Public Information, advertisements for Liberty Loans, and promotion of President Wilson's war aims - appeared alongside hagiographic accounts of Syrian soldiers. Next to enlistment in the army, purchasing Liberty Loans was the best way to 'prove that you are 100\% American', as a 1918 advertisement in al-Nasr (The Eagle) newspaper put it. ${ }^{55}$ In New York City, Syrian immigrants raised US $\$ 300,000$ in Liberty Loans by October 1918; the Boston-based Syrian American Club raised another US $\$ 18,750 .^{56}$ 'This organization is only as strong and radiant as its membership', wrote Mukarzil in June 1917, and 'those of us who are strong must use that strength in national service; those who are not strong must inspire the mighty and powerful'. 57

Syrian displays of pro-Entente patriotism signalled the community's proud participation in American political life, but they also included a second register, joining support for American war aims with the liberation of the Syrian homeland. The Syrian community's recruitment campaigns employed the language of Wilsonian self-determination, and 'establishing the right of peoples to determine their future' in Syria and Mount Lebanon remained the primary goal. ${ }^{58}$ Enlisting in the US army on behalf of Syrians still 'under the Turkish yoke' became an explicitly political act, reframing 'Syrian' (or 'Lebanese') identity into nationalist categories. In this sense, military mobilization was one of the clearest ways that the emigrants (to borrow Akram Khater's phrasing) 'became "Syrian" in America' through service and action. ${ }^{59}$ In New York City, the Lebanon League of Progress called young men to action as a matter of patriotism and masculine duty.

Second-generation Syrian Americans played a unique role in soliciting manpower from their communities. As American-born children with Syrian parents, these young men held US citizenship by virtue of birth. Eager to boost its voluntary enlistment numbers, the army sent these men back into their communities as recruiters before deploying them abroad. One of these young men was twenty-three-year-old Albert Hatem (see Figure 4). In addition to being the nephew of Na'um Hatem (a respected Syrian American author in Brooklyn), Albert was an heir of Hafid 'Id Hatem, a deputy in Mount Lebanon's governing Administrative Council before the war. ${ }^{60}$ With funds from the Lebanon League of Progress and the SyriaMount Lebanon League of Liberation, Hatem toured the southern United States in summer 1917, looking for recruits. He gave appearances in uniform with fellow soldiers Yusuf 'Abdu, Rashid Hajjar, and Ilyas Najmi, as well as Costa Najour and Dr Mitri Maseud. ${ }^{61}$ At a Syrian Greek Orthodox church in Atlanta, Hatem collected a dozen new men, all destined for the

53 'Syrians loyal to United States', Christian Science Monitor, 28 May 1917, p. 9.

54 Ibid.; NARA, RG 29, T626, roll 957, Records of the Bureau of the Census, Fifteenth Census of the United States, 1930, Massachusetts Census of Populations, Suffolk County, Boston City, District 13-514, Ward 20, page $9 \mathrm{~b}$, line 81 , Elias Shannon.

55 Bilingual Liberty Loan advertisement, 'La tathabbat marra wahida innaka Amriki bal mi'a marra / Prove you are $100 \%$ American', al-Nasr, 30 September 1918, p. 5.

56 Moroso, 'Fall of Damascus'; Arab American National Museum, Dearborn, MI, Evelyn Shakir Collection (henceforth AANM, ES), Syrian American Club of Boston Records, 1, 5.

57 Mukarzil, 'Fi kull yawm khitab'.

58 'Asas manh al-sh'ub huquq taqrir mustaqbaliha (The foundational rights of peoples to determine their future)', al-Huda, 2 June 1917, p. 2. See also Manela, Wilsonian moment, pp. 28-30.

59 Khater, 'Becoming "Syrian", p. 300

60 Ward, Kitab al-jundi al-Suri, p. 11.

61 On Costa Najour, see Gualtieri, Between Arab and white, pp. 60-2. 


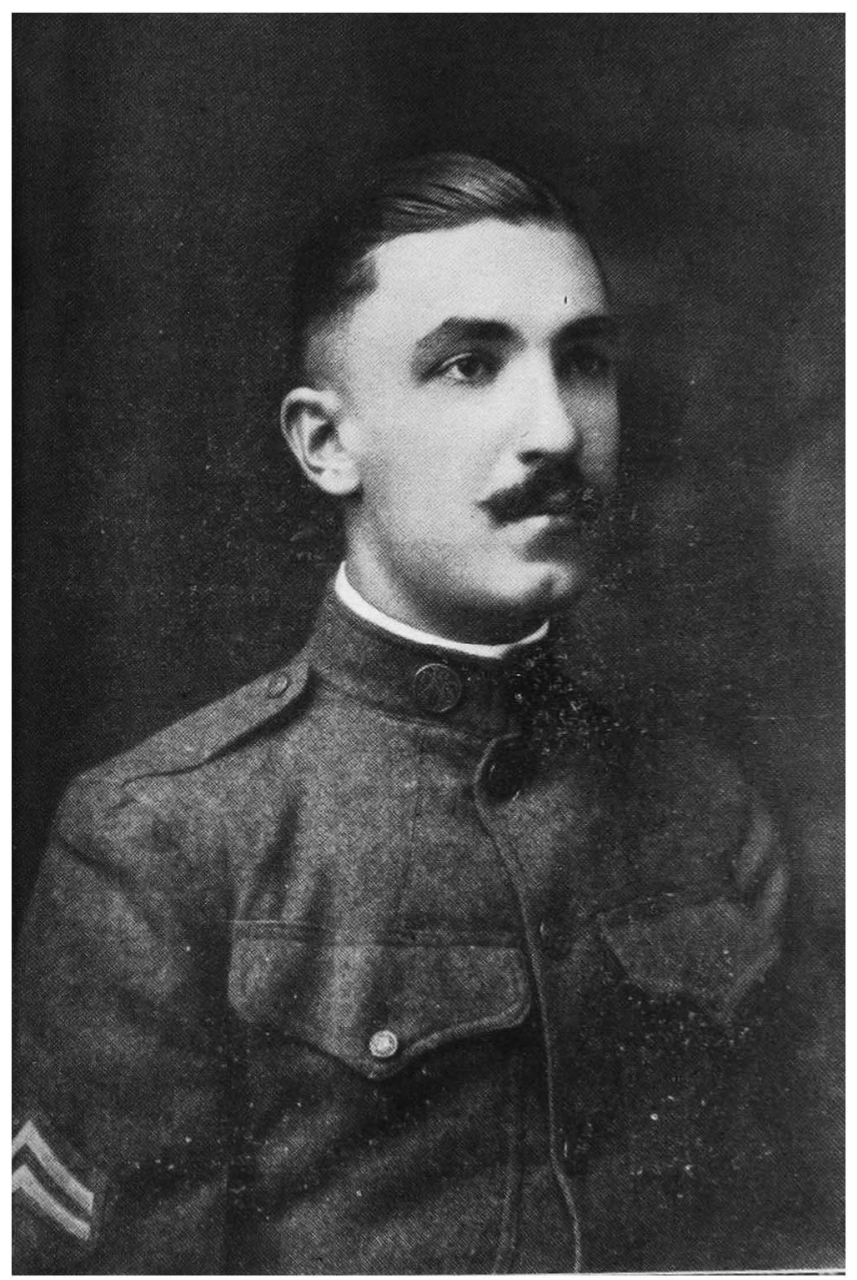

Figure 4. Albert Hatem, 1917. In 1918, Hatem was deployed to France with the 28th 'Iron Division', where he was promoted to Sergeant. Source: Ward, Kitab al-jundi al-Suri, p. 12.

Western Front, including Tanyus al-Najjar, Mihka'il 'Azzar, and Bishara Ma'luf. Hatem's colleague, Yusuf 'Abdu, reported to al-Fatat newspaper that the church also gave them a substantial cash donation for Syrian famine relief. ${ }^{62}$

Clergymen in both the Maronite and the Greek Orthodox rites sponsored recruitment events and provided men such as Albert Hatem with space for their activities. The Orthodox clergy took a particular interest in America's war effort and circulated statements in support of enlistment and its theological implications. Brooklyn's Orthodox archbishop, Basilius Kherbawi, summed up his stance in al-Sa'ih (The Traveller) newspaper in 1917: 'The present war has consumed the Christian world. Has it not been said to give unto Caesar what is Caesar's, and to God, what is God's? ... If a Christian is called to military service, he must give his

62 Yusuf Jirjis 'Abdu, 'Murasilat: Atlanta Jurjya, 1 Disimbir (Letters: Atlanta, Georgia, 1 December)', al-Fatat, 13 December 1917, p. 5. 
country what is asked of him. ${ }^{63}$ The justness of America's involvement provided additional reason: 'if the German nation and its Allies spread madness upon humanity, then isn't it upon every Christian to strike back at them for [the security of] their religion, civilization, and humanity?' Archbishop Kherbawi endorsed 'this recruitment campaign, and the Syrian Colony of America [which] leads the charge'. ${ }^{64}$

The clergy's involvement influenced the communal composition of Syrian immigrant enlistees: the Légion d'Orient was widely seen as a Maronite project, while enlistment in the US army stoked competition between Orthodox and Maronite leaders. But clerical support also produced complaints that the mobilization effort served sectarian agendas, particularly among émigré Sunnis and Druze, for whom continuing loyalty to the Ottoman empire's ruling party combined with a distrust of foreign ambitions in Syria. ${ }^{65}$ Their fears about sectarian discord linked directly to larger anxieties about foreign (particularly French) interference in Ottoman politics. ${ }^{66}$

The diaspora's experience with military mobilization also created significant political fissures between rival recruiters and among Syrian immigrant troops. The most common source of conflict lay in recruiters' preferences of foreign allies, as rival groups of Syrianists, Lebanists, and Arab nationalists each sought to raise their profile in Wilson's army. ${ }^{67}$ In New York City, Mukarzil's Lebanon League of Progress was the only group promoting the Légion d'Orient, but it also raised recruits for the US army and Mukarzil invested much of his time in attempting to cultivate American sympathies for Lebanese independence. Bakhash, the al-Fatat editor, by contrast, promoted mobilization as a means of securing American support for the Arab nationalist project of complete, immediate independence for a federated state including Syria, Mount Lebanon, and Palestine. 'The recruitment and deployment of fighters (mujabidin) for the Syrian cause', he wrote in December 1917, was for ultimate liberation (al-tabrir al-niha'i) from foreign occupation, Ottoman or otherwise. ${ }^{68}$ The city's Syrianist organization, the SyriaMount Lebanon League of Liberation, promoted cooperation with the Americans to form a constitutionalist state and 'a useful member in the society of civilized peoples ... under the separate and direct protectorship of a democratic Christian nation'. Its president, Ayyub Tabet, left the matter of Syria's foreign protector open, a move which put his organization at odds with Francophile Syrianist leaders such as Ghanim. Tabet also promoted the idea that America could help reconstruct war-torn Syria. In the first of many petitions to President Wilson, he stated his preference for an American mandate over Syria, but conceded that 'it is our sincere belief that the United States may not care to assume [this] responsibility'. ${ }^{69}$

The intense political rivalries that burned between recruiters also culminated in acts of sabotage. In 1917, Bakhash left New York for Argentina to promote the war to Syrian clubs in

63 Basilius Kherbawi, 'Hal yajuz li-l-Masihiyi an yatajannad? (Are Christians obligated to enlist?)', al-Sa'ih, June 1917, reprinted in Ward, Kitab al-jundi al-Suri, p. 116.

64 Ibid., p. 118.

65 Na um Mukarzil, 'Bayna al-Suriyyin: bi-ism al-Massih wa-l-Muhammad (Between Syrians: in the name of the Messiah and Muhammad)', al-Huda, 5 April 1916, p. 6; 'Abd al-Massih Haddad, 'Qatil bayna al-Suriyyin (Killing among the Syrians)', al-Sa'ih, 6 April 1916, pp. 1-2.

66 On confessional politics, see Stacy Fahrenthold, 'Transnational modes and media: the Syrian press in the mahjar and emigrant activism during World War I', Mashriq \& Mahjar: Journal of Middle Eastern Migration Studies, 1, 1, 2013, 40-1.

67 Hakim, Origins, pp. 1-13.

68 Bakhash, 'Nahu Suriya'.

69 NARA, RG 59, M367, roll 381, 763.72119/1686, E. Tabet and Mikhail Naimy to President Wilson, 10 May 1918. See also Ussama Makdisi, Faith misplaced: the broken promise of American-Arab relations, 1820-2001, New York: Perseus Books, 2010, pp. 136-46. 
Mendoza and San Martín. He quickly levied forty recruits, scheduled to accompany him back to New York. ${ }^{70}$ Back in Brooklyn, Mukarzil took advantage of Bakhash's absence to report his newspaper, al-Fatat, to the US Postmaster General, Albert Burlson. A brash nativist, Burlson had recently been empowered by America's Espionage Acts of 1917 to censor the city's ethnic press. ${ }^{71} \mathrm{He}$ required all foreign-language publications to remit regular English translations to his office for inspection, and al-Fatat's failure to do so in Bakhash's absence led to his indictment for sedition, along with two colleagues, Ilya Abu Madi (also at al-Fatat) and ${ }^{\mathrm{A}}$ Abd al-Massih Haddad (editor of $\mathrm{al}-\mathrm{Sa} \mathrm{a}^{3} \mathrm{i}$ ). ${ }^{72}$ Bakhash rushed home from Argentina to sort out the matter, leaving his recruits behind. He was later acquitted after Tabet prevailed on the French ambassador, Jean Jusserand, to write the US Department of State on his behalf. ${ }^{73}$

Syrian and Lebanese immigrants who joined the US army were, without exception, sent to France. Despite recruiters' description of the European front as a valid theatre in the war against the Ottomans, they faced ongoing pressure to facilitate the work of true auto-emancipation. Returning from a recruitment trip to Brazil in late 1917, Bakhash concluded that 'it is significant and important that Syrians may struggle for their own emancipation from the Turkish yoke' rather than awaiting liberation at the hands of European powers. ${ }^{74}$ Syrian battle deaths in faraway places such as the Somme and Château-Thierry weighed heavily on him. He feared that the 'unacknowledged and uncounted disappearance' of Syrian war dead in the mass carnage dissolved their symbolic significance and undermined the political contract he believed Syrians had made with America. ${ }^{75}$ Even as recruiters scoured the Americas looking for eligible young men, they lobbied for two changes in army policy to enhance Syrians' visibility: an end to the five-year residency period, which discouraged some Syrian declarants from volunteering, and a reconsideration of the US stance on irregular corps of co-ethnic immigrants.

Although the US army refused to loosen its eligibility requirements for foreign-born soldiers in 1917, circumstances changed dramatically the following year. What had seemed like an elegant classification system dividing immigrants into declarants, non-declarants, and ineligible aliens instead proved to be a messy, unworkable albatross. Because the Selective Service Act required all immigrant men to register despite their actual eligibility, hundreds of thousands of ineligible aliens were mistakenly drafted into the army, among them thousands of Ottoman subjects. Some filed grievances through the foreign consular system; in the United States, the Spanish Consulate handled exemption claims on behalf of Ottoman immigrants. ${ }^{76}$ But the exemption process was difficult and required drafted men to actively petition for exemption. Exemption fraud also became a problem. ${ }^{77}$ If some immigrants used forged papers to claim

70 Tannus Yusuf Doumit and Shukri al-Bakhash, 'al-Bakhash wa-1-mudafi in salafan (Bakhash and the ranks of the defenders)', al-Huda, 1 May 1917, p. 2.

71 Christopher Capozzola, Uncle Sam wants you: World War I and the making of the modern American citizen, New York and Oxford: Oxford University Press, 2008, pp. 152-9.

72 Na um Mukarzil, 'Akhbar mahliyya: tajrim sihafiyyun (Local news: journalists indicted)', al-Huda, 4 May 1917, p. 2.

73 NARA, RG 59, M367, roll 217, 763.72112/5267, Jean Jusserand to Robert Lansing, Secretary of State, 'Memo 5267, on behalf of A. Tabet', 24 October 1917.

74 Bakhash, 'Nahu Suriya'.

75 Ibid.

76 NARA, RG 65.2.2, M1085, Investigative reports of the Bureau of Investigation, case no. 84061, Perkins, 'Naoum Mokarzel-French Consul—Spanish Consul, alleged interference of Spanish Consul with Selective Draft of Syrians in the United States', 28 January 1918, pp. 16-17.

77 NARA, RG 65.2.2, M1085, roll 751, case no. 329549, Busha, 'Alli Muharem, alleged representing himself as Turkish consul', 19 November 1918. See also 'Gross frauds on draft suspected: follows arrest of Joseph Solomon and Said Joseph’, Boston Daily Globe, 15 January 1918. 
exemption from the draft, many more opted to serve despite being legally ineligible; Nancy Ford enumerates some 191,000 illegal US army enlistments by the war's end. ${ }^{78}$

Meanwhile, ethnic leaders in several immigrant communities pushed for a loosening of restrictions, and mainstream American nativists complained about 'alien slackers' who had been excused from military service. ${ }^{79}$ Congress revisited the issue of immigrant military service in 1918, drafting a new law that waived the five-year residency requirement for immigrant volunteers in the armed forces. The 9 May 1918 Act

entitles all aliens in the service (including enemy aliens) to citizenship whether they have their first papers or not ... Before the application is granted, however, it should be understood that the application is wholly voluntary and is a privilege which can only be granted to those producing evidence of loyalty ... When the application is granted, the soldier will immediately become a citizen, with all privileges and immunities of citizenship. ${ }^{80}$

This instantaneous citizenship was available only to immigrant soldiers, but regardless of declarancy or nationality status. A single witness, usually the recruit's commanding officer, was the army's standard for 'evidence of loyalty'. After signing a naturalization petition and a loyalty oath renouncing their previous nationality, the soldiers proceeded to base camp as new American citizens. ${ }^{81}$

The 9 May Act bolstered a new wave of enlistment enthusiasm among Syrian American activists. The Syrian American Club had long focused on 'forging ties of love and reconciliation between the Syrians, assistance [to Syrians] in obtaining American citizenship, and the defense of Syrian Americans from all classes in either of these endeavors', but in summer 1918 it sponsored dozens of new applications aimed at joint naturalization and enlistment. ${ }^{82}$ Its recruiters in the Boston area, Wadi' Shakir and Ibrahim al-Khuri, promoted military service as the best means of achieving American citizenship.

The recruitment process was almost invariably managed by newspaper editors and other nationalist elites, but Syrian enlistees represented the full spectrum of the diaspora's working and middle classes. Most of the men whom Shakir and al-Khuri levied in 1918 were textile workers from New England, and improved access to US citizenship appealed more to Syrian proletarians than it did to the peddlers, merchants, and intellectuals who dominate studies of the Syrian diaspora. A boom in the American textile industry just prior to the war led many Syrian men into industrial weaving, leatherworking, and heavy manufacturing. Cash wages in these industries had reached an all-time high, but unnaturalized Syrian workers also found themselves underpaid relative to naturalized immigrant workers. First-time army privates earned only US\$15 a month, a paltry sum compared to the US\$25-30 that skilled textile workers made. But Syrian enlistees who fulfilled at least one term in the army could then make use of their new citizenship status to obtain higher wages at the factories that

78 Ford, Americans all, p. 56.

79 See 'Alien slackers may not escape service', New York Times, 22 April 1917, p. 3; 'Deportation of alien slackers', Christian Science Monitor, 1 August 1917, p. 1.

80 War Department organizational records, 77 th Division records, Office of the Chief of Staff, memorandum no. 79, 21 May 1918, cited in Ford, Americans all, p. 63.

81 Ford, Americans all, p. 64.

82 AANM, ES, Syrian American Club Records, 1, 6, Shukry Yusuf, 'Syrian American Association bylaws', 10 October 1914. See also Gualtieri, Between Arab and white, p. 85. 
employed them; those who stayed longer quickly advanced in rank, commanding monthly salaries as high as US\$50. ${ }^{83}$ The men who came to Shakir and al-Khuri did so in groups, having resolved to join the army together on the shop floor. ${ }^{84}$ In one case, a shop foreman named Jurj Ma'tuq brought several employees from a Boston-area shoe factory. Ma'tuq was an American citizen by virtue of birth; born in Boston to Syrian parents, he sponsored new enlistment applications until his own deployment as an army translator in 1918. Ma'tuq's name also graces the naturalization papers for several Syrians (all leatherworkers) under the 9 May Act. ${ }^{85}$

The US army also revised its policies regarding ethnic corps in mid 1918. Historically the Americans had resisted the use of irregular legions like the French Légion d'Orient because of concerns about the diplomatic entanglements that such units could produce. An early effort to levy an all-Syrian legion in Fall River, Massachusetts, failed to secure army approval. In this small mill town in 1917, a naturalized army veteran named Mitri Jabbur raised an informal column of 300 Syrian men running daily drills at the police academy. It is unclear whether Sgt Jabbur had army authorization, but Fall River's municipal authorities endorsed the project as a show of immigrant patriotism. In his appeal to the US army's Provost Marshall, Sgt Jabbur stated that his goal was deployment to Mount Lebanon. Upon learning of the exercises, General Crowder instead ordered the corps to be disbanded. ${ }^{86}$

Several immigrant groups lobbied for new ethnic corps in 1917, and the US army systematically denied these requests, typically referring them to one of America's allies. Vladimir Jabotinsky's efforts to recruit American Jews for the Zion Mule Corp (later the Jewish Legion) are instructive. With volunteers from New York, Boston, and Chicago, Jabotinsky petitioned for American sponsorship to bring the company to Palestine on behalf of Jewish settlers there. President Wilson declined to support Jabotinsky's project; instead, he obtained British backing in 1917 and landed in Palestine with 10,000 recruits. Notably, half of the Jewish Legion's fighters were American citizens granted service exemptions by the US government. ${ }^{87}$ Naturalized Syrian immigrants who served under the French flag in the Légion d'Orient were similarly exempted from the American draft. ${ }^{88}$

The 9 May 1918 Act prompted the US army to experiment with a variety of ethnic legions for the first time, changing the nature of immigrant mobilization as Syrians motivated by a desire to renounce their Ottoman nationality and gain US citizenship joined in larger numbers. In the summer of 1918, eight new battalions began training at Camp Devens in Massachusetts. ${ }^{89}$ The regiments - Italian, Russian, Polish, Lithuanian, Greek, Albanian, Syrian, and Armenian - trained and spoke in their own languages and were comprised entirely of

83 War Department, 'Rates of monthly pay for enlisted men', Official Army register December 11918 , Washington, DC: Government Printing Office, 1918, pp. 1138-9. Donald Cole, Immigrant city: Lawrence, Massachusetts 1845-1921, Chapel Hill, NC: University of North Carolina Press, 1963, p. 183.

84 AANM, ES, Syrian American Club Records, 1, 6, 1918.

85 See, for instance, NARA, RG 21, Records of the US District Court, M1368, roll 99, Petitions and records of naturalizations of the U.S. District and Circuit Courts of the District of Massachusetts, Petition for naturalization of Peter Arthur Abraham, 9 May 1919.

86 Sa'ab, 'Hawl harakat al-tatawwu' al-wataniyya (About the national voluntary recruitment movement)', al-Huda, 5 May 1917, p. 5.

87 Ford, Americans all, pp. 37-9.

88 Tauber, Arab movements, p. 201. Such was the case of Melham George, investigated for draft evasion in 1918 but subsequently cleared because he was 'fighting the Turks in Palestine' with the French: NARA, RG 65.2.2, M1085, roll 692, case 277009, Dunn, 'Visa investigation, Melham Maroum George', 30 August 1918.

89 'Organize "foreign legions" at Devens: War Office experiments with new scheme', Daily Boston Globe 17 August 1918. 
immigrants given naturalization in return for service. ${ }^{90}$ Sergeant James Habib 'Attara, a leatherworker originally from Aleppo, presided over the Syrian column. 'Attara's group was earmarked for France, but did not deploy because the war ended before they completed training. The Syrian legion's naturalization paperwork was so hastily drawn up (and so slowly processed) that many of the men training under 'Attara formally remained Ottoman subjects until after the Armistice. Sgt 'Attara's own citizenship papers, for instance, were not processed until 22 November 1918, two weeks after the end of the First World War. ${ }^{91}$

\section{The hajj to break the German empire: Syrian soldiers on the Western Front}

Despite the recruitment obstacles that Ottoman immigrants faced, many Syrians and Lebanese successfully enlisted and deployed to Europe under French, Canadian, British, and American flags. The Syrian press in the diaspora printed their images, biographies, and letters, eagerly documenting Syrians on their ' hajj to break the German empire'. ${ }^{92}$ A genre emerged that folded soldiers' stories into a pervasive narrative about Syrian liberation from abroad, ultimately serving the ends of recruiters and a variety of émigré nationalists. But Syrian and Lebanese deployment experiences illustrate a variety of responses to life in combat, undermining the confident patriotism imposed on them by the press abroad. Mounting casualties, the drudgery of trench life, and brazen attempts by nationalists to appropriate the soldiers as symbols for their political projects indelibly marked recruits' perspectives of the war. For them, the simultaneity of 'Syrian' and 'American' patriotism - so important during the enlistment process - began to break down.

Writing home from the Western Front, deployed Syrians frequently reported their discovery of compatriots on the battlefield. Sometimes this was a source of glee: in late 1915, Gabriel Ward reported to Ibrahim al-Khuri and the Fatat Boston newspaper that some of the Syrians fighting in Britain's regiments were Ottoman draft-dodgers who had fled Mount Lebanon early in the war and 'had been offered refuge in Britain' in return for their service. ${ }^{93}$ Though few in numbers, Ottoman army deserters who joined the Entente gave the Syrian press a powerful symbol for émigré partnerships against Istanbul. Discussions about the empire's eroding military morale accompanied images of Syrian troops and advertisements calling for recruits. ${ }^{94}$ To encounter an Ottoman deserter in Europe was not typical, however; the British principally employed them in the Hejaz, working as saboteurs with Emir Faysal's Arab forces. ${ }^{95}$ But Syrian troops stationed in Europe often met other Syrians blended together in infantry units from across the diaspora in ways that facilitated new discussions about what it meant to be 'Syrian', 'Lebanese', or 'Arab' as opposed to 'Ottoman' in the context of war.

90 Laurence Winship, 'Camp Devens foreign legion presents a Babel of tongues: Slav and Italian and Greek and Armenian, but all Americans at heart', Daily Boston Globe, 25 August 1918, p. 32.

91 NARA, RG 21, Records of the US District Court, M1368, roll 99, Petitions and records of naturalizations of the U.S. District and Circuit Courts of the District of Massachusetts, Petition for naturalization of James Habib Attara, 22 November 1918.

92 Ward, Kitab al-Jundi al-Suri, p. 112.

93 Ibid., p. 101.

94 Beşikçi, Ottoman mobilization, p. 259.

95 NARA, RG 59, M 367, roll 381, 763.72119/1707, William Yale to Leland Harrison, Department of State, 'Report \#2 dealing with Arabia and Hedjaz situation', 5 November 1917, pp. 18-19. See also Beşikçi, Ottoman mobilization, pp. 257-64; Eugene Rogan, The fall of the Ottomans: the Great War in the Middle East, New York: Basic Books, 2015, pp. 302-5. 
Although 'Syrian' identity had carried a specific ethnic content and legal value in the Americas since the late 1890s, the experience of mobilization of Syrian co-ethnics promoted political identifications as 'Syrian' or 'Lebanese', with increasingly nationalist trappings.

Writing to New York's al-Huda newspaper in 1917, Ward described an afternoon in a London café known as a haunt for Syrian soldiers. Sipping coffee with a group of uniformed Syrian Christians, he was discussing Mount Lebanon's famine when the café owner, a Muslim named Sa id who identified as a supporter of Emir Faysal's Arab Revolt, inserted himself into the group: 'the famine, the war; they are all signs of God's wrath'. Ward replied, 'the wrath of God, as you say, or that of Government?' The coffeemaker interjected, 'God curse the Unionists [the Committee of Union and Progress, Istanbul's ruling party] ... no Muslim starves or hangs his people'; noticing the men's uniforms, he asked if they were 'those men recruited by the Lebanon League of Progress?"96 Ward denied this but voiced his support for Mukarzil's campaign as a means of 'Syrian and Lebanese emancipation'. Ward's distinction of 'Syrian' from 'Lebanese' reflected the diaspora's emerging nationalist idioms, but it was a distinction that Hashimite Arab nationalists and the majority of Ottoman Syria's inhabitants sharply rejected. ${ }^{97}$ Unimpressed by Ward, Said made his appeal for pan-Arab unity against the Ottoman state,

Brother, after this war we will all be together, not as 'Syrian' or 'Lebanese'. Please, I ask you to pass on my words to every colony and corner of your diaspora: that they are not Christian, nor Lebanese, nor Syrian. All of us are Arabs in a Turkish house ... we are all under a single shadow, and no work can be done [about it] unless we do it together. ${ }^{98}$

Among soldiers, the experience of recruitment, enlistment, and deployment effectively changed what it meant to be 'Syrian' or 'Lebanese' as opposed to Ottoman subjects abroad. By 1918, new national signifiers took on increasingly more rigid ideological content.

At the same time, soldiers' writings betrayed a countervailing resistance to nationalist ideas, as well as a mounting belief among the men that the war would destroy, not create, new nations. The war's global character and the Western Front's massive mortality alienated Syrian troops from the nationalist goals reported by activists abroad. In his memoirs, Ward recounted the combat death of a close companion from his regiment, Jibrail Bishara from Mount Lebanon. Ward and Bishara had travelled together from New York to Canada to enlist in 1915. Ward recalled his eagerness to 'to complete the salvation of Syrians and Lebanese from the suffering of this war' as they arrived in northern France in January $1916 .{ }^{99}$ Bishara had been 'the first to charge into the battlefield', where he instantly sustained a mortal shrapnel wound to the neck. As he lay dying in a field hospital, his final thoughts were taken down by Ward. These he sent to the Syrian newspapers of New York:

you listen to me, dear Gabriel, do not risk yourself recklessly as I have, for my prize will be that I die in this strange, foreign place, without seeing my family, my friends, or my neighbours once more. Write to them in the mahjar [diaspora] and tell them how I have been killed. Tell them that I have gone in martyrdom back to my homeland, where I pray

96 Gabriel Ilyas Ward, 'Hadith al-Muslim (A discussion with a Muslim)', al-Huda, 11 May 1917, p. 5.

97 Kayal, Arabs and Young Turks, pp. 174-202; Çiçek, War and state formation, pp. 39-63.

98 Ward, 'Hadith al-Muslim'.

99 Ward, Kitab al-jundi al-Suri, p. 10. 
there will soon rise a liberated Syria and Lebanon, free from the nations of Genghis Khan. ${ }^{100}$

Bishara's words raise a curious blend of notions of martyrdom for the cause of national liberation with his doubts about fighting Syria's war from the wrong side of the world. His complaint took aim at a central promise made by émigré recruiters: that Syrian soldiers fighting anywhere contributed to their homeland's independence. Mailing the declaration to al-Huda and al-Sha'b (The People) newspapers, Ward noted with bitter irony that Bishara's death (not his deployment) delivered him home. Some months later, trench life exposed Ward to toxic gas, depriving him of sight in one eye and the use of his left hand. He was reassigned to London, where he worked as an intelligence officer monitoring the city's Syrian periodicals, ethnic societies, and cafes for 'pro-German sympathies' (and it was in this work that he encountered Sa id, the Arab nationalist café owner). ${ }^{101}$ Ward also promoted recruitment for the Légion d'Orient and to the Ottoman fronts generally. ${ }^{102}$

Ward's later dispatches to al-Huda illustrated his mounting frustration with the suffering he encountered on the European front. In 1917, he described a meeting with an Ottoman deserter hiding out in France. The man 'had death in his eyes. He had witnessed true alienation and had a severe, strained countenance' as he asked Ward for help in joining the French infantry. Ward reported that, when he asked why he wished to join the Allies, the deserter chillingly replied 'Are we not all alienated? Are we not, all of us, fighting together? As this war heaps ever greater numbers of us, corpses and fleeing soldiers, atop one another, we shed our contrasting colours and are joined in mutual fear. ${ }^{103}$ If Ward had described Bishara's death as a sort of national homecoming in 1916, this exchange comes to a grimmer conclusion: mortality as the means by which men cast off their nationalist raiment and are ground back into an undifferentiated, suffering humanity.

Back on the American home front, Syrian newspapers were undeterred. They continued to celebrate the community's deployed troops and facilitated the ongoing recruitment efforts of their editors. But soldiers' experiences abroad differed significantly from the expectations of émigré nationalists, producing moments of intense friction when the latter appropriated recruits as nationalist symbols. After enlisting with a group of Syrian leatherworkers in Boston, Jurj Matuq deployed to northern France in 1918, working as a translator for the 101st Engineer Corps. Once abroad, he wrote home to Fatat Boston to request that the immigrant community send care packages to his deployed compatriots. ${ }^{104}$ The newspaper featured Ma'tuq's note on page 1, with the biographies of 'entrenched Syrians' on the Western Front. ${ }^{105}$ Its editor, Wadi' Shakir, also wrote a full-page editorial applauding Ma'tuq and plugging his Syrian American Club recruitment work. 'We Syrians', Shakir began,

100 Ibid., p. 122. Bishara's derisive terminology, 'the nations of Genghis Khan' (al-dawla al-jankiziyya), was a common soldier's idiom referring to the German forces. In Syrian usage the epithet also captured notions about the Ottomans as Turkish hordes.

101 AANM, ES, Syrian American Club Records, 1, 5, Gabriel Ward to Syrian American Club of Boston, 23 November 1918; Ward, Kitab al-Jundi al-Suri, p. 70.

102 'Ahad jabarat al-Suriyyun (One powerful Syrian)', Abu al-Hawl, May 1917, and 'Jundi yada'u al-Suriyyin wa-l-Lubnaniyyin ila-l-tatawwu' (A soldier calls on Syrians and Lebanese to volunteer)', al-Huda, May 1917, reproduced in Ward, Kitab al-jundi al-Suri, pp. 125-9.

103 Ward, "Ar an la-tasil dama'una illa 'ala khanja al-saffah'.

104 NARA, RG 147, M2097, roll 185, Selective registration cards, World War II, no. 1753, fourth registration for George A. Matook, 1942.

105 Wadi' Shakir and Jurj Ma'tuq, 'Risala jundi Suri (A Syrian soldier's letter', Fatat Boston, 3 March 1918, p. 1. 
We grow up abhorring the military lifestyle, and we live timid lives in fear and bitterness. Then there are those of us who go to service and face a world of death. Those feelings of fear and timidity are in the hearts of every young Syrian because of the Turkish government's brutality, of shortages and starvation ... [but] they can draw on these hatreds to fight off eons under the Turkish yoke. ${ }^{106}$

Shakir left no room for ambiguity: these soldiers were engaged in a battle against the Ottoman state on behalf of Syrians around the world. He probably thought that Ma'tuq would approve of his narrative; instead, Ma'tuq was outraged.

Upon reading about his unit in Fatat Boston, Ma'tuq penned a second, deeply critical letter to Shakir and the Syrian American Club in June 1918. As a Syrian American, he saw himself as principally engaged in 'a fight to the end for the stars and stripes, that flag of liberty and democracy'. ${ }^{107}$ He resented his name being attached to a discussion of homeland politics, and he felt that Shakir had capitalized on the lives of his fellow soldiers:

You are acting as Americans, in America, [but] are you really Americans, or are you only Americans for your busnis [sic]? I just wonder what your idea was in taking our name, our company's name and regiment address. I gust [sic, 'guessed'] it was so you could remembre [sic] us when we die. Or was it to write to each other and attach your club to us, same as all the other [immigrant] clubs? I would just like to find out ... what kind of Americans you really are. We [are] in France doing our bit, what are you fellows doing ? $^{108}$

Ma'tuq invoked what he saw as the fundamental distinction between Syrian soldiers and the émigré nationalists responsible for recruiting so many of them. For the nationalists, soldiers were a symbol of Syria's liberation and redemption. For Ma tuq, by contrast, they were agents of liberation: 'We [are] not fighters only where we [were] born but we are fighting for Syria too and Liberty. God is leading us to Liberty, bearing our flag on his Right and France on his left, heading us towards Liberty and home.' Ma'tuq had little patience with the elite nationalists of the pen, and he closed his letter with a challenge to Shakir to write to deployed Syrians, rather than about them in the press: 'even if they are not a member of your club, they are your own nationality, your kind, the same as the Italian, the Jew, and the Polish ... why should we let somebody else [be] better than us? ${ }^{109}$

Ironically, Ma'tuq's multilayered patriotism - as simultaneously 'Syrian' and 'American' had already started to fall out of style among nationalist elites such as Shakir in favour of programmatic nationalist agendas concerned with the 'Syrian Question', Wilsonian selfdetermination, and the emergence of new national borders on the Middle Eastern map. The recruitment of emigrants had depended on a flexible, multi-layered patriotism appealing to desires for both Syrian liberation and American inclusion, but the post-war movement would depend on unambiguous claims to national territories, histories, and identities. At the precise moment that Syrian soldiers expressed their frustrations with the limitations of nationalist discourse, activists abroad promoted these same nationalisms to policymakers in the Entente.

106 Wadi' Shakir, 'al-Suri al-mutajannad (The entrenched Syrians)', Fatat Boston, 3 March 1918, p. 2.

107 Shakir and Ma'tuq, 'Risala jundi Suri'.

108 AANM, ES, Syrian American Club Records, 1, 5, Jurj Ma'tuq to Syrian American Club of Boston, 4 June 1918. Ibid. 


\section{Conclusion}

The First World War ended in the Ottoman empire's defeat in October 1918, and with Syria's occupation by British, French, and Arab troops. The League of Nations announced that it would preside over the post-war settlement process at the 1919 Paris Peace Conference and dozens of émigré recruiters-turned-nationalists shifted focus from mobilizing the diaspora's military manpower to harnessing its representative voice through extensive petition campaigns. ${ }^{110}$ In their production, circulation, and presentation to the Great Powers, petitions on the 'Syrian Question' followed the same routes that once delivered Syrian troops to enlistment centres. Often, these documents passed through the same networks of men whose hands had stamped foreign passports, drawn up naturalization papers, and provided steamship tickets to emigrant troops one year earlier.

Military mobilization in the Syrian diaspora began in 1916, with the French campaign to enlist migrants into the Légion d'Orient. The French campaign provided a highly visible model for transnational recruitment which Syrian émigrés employed with larger success later, as the United States of America entered the war in 1917. Thousands of Syrians and Lebanese from both North and South America, many of them recent Ottoman nationals, enlisted in the United States army. Their recruitment required the construction of sophisticated networks of men to solicit manpower, challenge the legal ambiguities that foreign nationals faced, and negotiate the terms of enlistment, deployment, and citizenship for Syrian soldiers. Starting in 1916 with French efforts to train a Syrian ethnic corps, recruitment of Syrian and Lebanese emigrants fostered new patterns of migration between the diaspora's outposts in North and South America. Recruits could be filtered through French, Canadian, and American channels on the basis of recruiters' political loyalties, soldiers' citizenship or confessional status, opportunities for naturalization, or choice of active fronts. For many recruits, service under the American flag was preferable, especially after the 9 May 1918 Act offered instantaneous American citizenship to Syrian volunteers.

Through a fragmentary archival record and the reportage from the Arabic press, this article has captured what Syrian diasporic mobilization looked like from the inside, through the eyes of recruiters and their emigrant charges. It has argued that the mobilization effort depended on a flexible, multivalent discourse about patriotism, responsibility, and obligation that spoke to emigrants as both Syrians and Americans. Recruiters built into their work with the US army the expectation that the use of Syrian troops would lead to an American endorsement of Syrian aspirations for independence. In the end, these expectations were sorely frustrated: an emigrant bid for a US mandate over Syria and Lebanon failed to capture the attentions of American policymakers, and France prepared the ground to impose a League of Nations mandate in 1920. ${ }^{111}$ As for the Syrian immigrant veterans who served, most of them secured American citizenship but maintained a fluid, situational political identity: simultaneously Syrian and American, and as migrants with familial, commercial, and affective ties to the new states of

110 On petitions, see Susan Pedersen, The guardians: the League of Nations and the crisis of empire, Oxford: Oxford University Press, 2015; Hakim, Origins, pp. 213-60; Arsan, 'This age', p. 137; Jackson, 'Diaspora politics', pp. 166-90; Reem Bailony, 'Transnationalism and the Syrian migrant public: the case of the 1925 Syrian Revolt', Mashriq \& Mahjar: Journal of Middle East Migrations, 1, 1, 2013, pp. 21-4; Natasha Wheatley, 'Mandatory interpretation: legal hermeneutics and the new international order in Arab and Jewish petitions to the League of Nations', Past \& Present, 227, 2015, pp. 205-48.

111 Makdisi, Faith misplaced, pp. 145-55; Blumi, Ottoman refugees, pp. 146-50; Manela, Wilsonian moment, p. 147. 
112 STACY D. FAHRENTHOLD

Syria and Lebanon. Homogeneous, exclusive concepts of national identification - Syrian, or Lebanese, or American but never all of these - had never much suited them.

Stacy D. Fabrenthold is a visiting scholar at the Center for Middle Eastern Studies at the University of California, Berkeley. 